\title{
CHARISTHEO
}

Jurnal Teologi dan Pendidikan Agama Kristen

Sekolah Tinggi Teologi Anugrah Indonesia

Print ISSN: 2541-5247

http://e-journal.anugrah.ac.id/index.php/JCH

Vol. 1 No. 1, September 2021

Submitted: 2021-07-09

Reviewed: 2021-07-13

Accepted: 2021-07-29

\section{TINJAUAN ETIS KRISTEN TERHADAP KEBEBASAN BERAGAMA DI LINGKUNGAN SEKOLAH NEGERI DENGAN DICABUTNYA SKB TIGA MENTERI}

\author{
${ }^{1}$ Suriawan Surna*, Priyantoro Widodo ${ }^{2}$ \\ $1 \& 2$ Sekolah Tinggi Teologia Baptis Indonesia \\ *Email Correspondence: suriawansurna@stbi.ac.id
}

\section{ABSTRACT}

In order to protect the equal right to freedom of thought, belief and religion of all students in all public schools in Indonesia; in February 2021, the central government represented by three ministers, namely Minister of Education and Culture, Home Affairs Minister, and Religious Affairs Minister issued Joint Ministerial Decree (SKB) on the Use of Uniforms and Attributes for Students, Educators, and Education Personnel in state schools at the primary and secondary level .On 3 May 2021, the Supreme Court of the Republic of Indonesia revoked it. The purpose of this paper is to state a universal Christian ethical attitude in the midst of national and state life which is based on Pancasila and Bhineka Tunggal Ika ("Unity in Diversity"), especially in response to the revocation of the 3 Ministerial Decree that used to guarantee and protect religious freedom in state schools. The method used in this paper is phenomenological-qualitative research. The result is hoped to become a consideration for the central government and every child of the nation in general, and especially for followers of the Lord Jesus Christ in the land of Pancasila, Indonesia.

Keywords: freedom of religion, Christian ethics, universal

\begin{abstract}
ABSTRAK
Demi menjaga kebebasan dalam mengekspresikan keyakinan yang dianut semua siswa di semua sekolah negeri di Indonesia, maka pemerintah pusat yang diwakili tiga Menteri yaitu Menteri Pendidikan dan Kebudayaan, Menteri Dalam Negeri, dan Menteri Agama mengeluarkan Surat Keputusan Bersama (SKB). Penggunaan Pakaian Seragam dan Atribut bagi Peserta Didik, Pendidik, dan Tenaga Kependidikan di Lingkungan Sekolah yang diselenggarakan Pemda pada Jenjang Pendidikan Dasar dan Menengah pada bulan Februari 2021. Namun SKB tiga Menteri tersebut terkesan mengekang dan membatasi tradisi atau budaya masyarakat yang sudah lama ada di daerah di Indonesia. Pada tanggal 3 Mei 2021, Mahkamah Agung Republik Indonesia mencabut SKB 3 Menteri tersebut. Tujuan dari makalah ini adalah untuk menyatakan sikap etis Kristen di tengah-tengah kehidupan berbangsa dan bernegara yang berdasarkan Pancasila dan Bhineka Tunggal Ika dalam menyikapi ketiadaan SKB 3 Menteri yang menjamin dan melindungi kebebasan beragama di lingkungan sekolah negeri. Metode yang digunakan di dalam makalah ini adalah metode penelitian fenomenologikualitatif. Hasilnya diharapkan menjadi pertimbangan bagi pemerintah pusat dan setiap anak bangsa pada umumnya serta khususnya bagi pengikut Tuhan Yesus Kristus di bumi Pancasila, Indonesia.
\end{abstract}

Kata Kunci: Kebebasan Beragama, Etika Kristen, 


\section{PENDAHULUAN}

Peristiwa pengekangan kebebasan mengekspresikan keyakinan agama melalui penggunaan atau pelarangan atribut seragam sekolah yang sudah menuju tindakan intoleransi agama di sekolah negeri sudah terjadi di beberapa daerah di Indonesia. Beberapa peristiwa tersebut antara lain ditemukannya pelarangan penggunaan jilbab bagi siswi beragama Islam di pulau Bali pada tahun 2014, pada tahun 2017 di SMAN 1 Maumere pulau Flores di provinsi NTT, dan pada tahun 2019 di SD Inpres 22 Wosi Manokwari di provinsi Papua Barat. Terakhir terjadi di tahun 2021 di SMKN 2 Padang, Sumatera Barat dimana siswa non muslim diwajibkan menggunakan jilbab di lingkungan SMKN 2 Padang. Demi menyikapi kasus-kasus pengekangan kebebasan beragama tersebut pemerintah pusat melalui tiga Menteri yaitu Menteri Pendidikan dan Kebudayaan, Menteri Dalam Negeri, dan Menteri Agama mengeluarkan Surat Keputusan Bersama (SKB) tentang Penggunaan Pakaian Seragam dan Atribut bagi Peserta Didik, Pendidik, dan Tenaga Kependidikan di Lingkungan Sekolah yang Diselenggarakan Pemda pada Jenjang Pendidikan Dasar dan Menengah.

Penerbitan SKB 3 Menteri tersebut ditanggapi masyarakat luas dengan pro dan kontra. Salah satu organisasi masyarakat yang kontra adalah Lembaga Kerapatan Adat Alam Minangkabau (LKAAM) Sumatera Barat. Mereka mengajukan permohonan uji materiil terhadap SKB 3 Menteri Nomor 02/KB/2021, Nomor 025-199 Tahun 2021, Nomor 219 Tahun 2021 kepada Mahkamah Agung dan hasilnya pengabulan permohonan uji materiil yang diajukan. Hasil akhir dari keputusan ini adalah keluarnya perintah dari Mahkamah Agung untuk pencabutan SKB 3 Menteri tersebut. Dengan demikian peserta didik yaitu siswa, guru, dan kepala sekolah negeri di setiap provinsi di Indonesia kembali kepada Undang-Undang Nomor 23 Tahun 2014 tentang Pemerintah Daerah berhubungan dengan seragam sekolah. Di dalam undang-undang tersebut setiap daerah dapat mengeluarkan peraturan daerah mengenai penyelenggaraan pendidikan yang disesuaikan dengan kondisi di daerahnya dalam hal ini adalah agama mayoritas penduduk.

Tanpa adanya SKB 3 Menteri yang dicabut oleh Mahkamah Agung, maka dapat terulang lagi tindakan intoleransi agama di lingkungan sekolah yang dikelola oleh pemerintah dalam hal ini pemerintah daerah. Anak-anak Indonesia memiliki hak untuk bersekolah di sekolah negeri, dan setiap dari mereka termasuk secara tidak langsung orang tua, dan pelaksana pendidikan diwajibkan untuk mengikuti seluruh peraturan di sekolah termasuk penggunaan atribut seragam yang dapat berlawanan dengan keyakinan agama. Ada ancaman pendisiplinan sampai dikeluarkan dari sekolah jika tidak tunduk pada peraturan yang dibuat oleh sekolah. Ini adalah problematika nyata yang 
harus dihadapi siswa serta orang tua siswa, dan juga guru serta kepala sekolah negeri. Bagaimana problematika ini ditinjau dari etis Kristen dan apa solusi etika Kristen untuk pemerintah pusat dan setiap individu warga negara Indonesia terhadap kasus intoleransi agama yang dapat terulang di lingkungan sekolah negeri. Solusi yang diambil haruslah mengandung nilai universal yang menjadi bagian dari falsafah bangsa yaitu Pancasila. Terlebih orang kristen sejatinya memahami bahwa di segala situasi dan kondisi apapun yang terjadi tetap memberikan kontribusi bagi kemajemukan bangsa Indonesia (Simon \& Arifianto, 2021).

\section{METODE PENELITIAN}

Di dalam mencapai tujuan penulisan artikel ilmiah ini, penulis memakai metode fenomenologi kualitatif, dimana penelitian kualitatif digunakan untuk dapat memahami suatu fakta (Morissan, 2019). Penelitian kualitatif menggunakan contoh atau sampel dalam jumlah kecil dalam hal ini kasus-kasus pengekangan kebebasan beragama di sekolah negeri di Indonesia. Penelitian kualitatif ini berorientasi kepada sejumlah fakta atau kasus yang fenomena yaitu pengekangan mengekspresikan kebebasan beragama di lingkungan sekolah negeri seperti di Bali, Maumere, Manokwari, dan Padang. Menurut Morissan penelitian dengan metode fenomenologi fokus kepada apa yang dialami oleh manusia yang berhubungan dengan suatu fenomena dan bagaimana fenomena tersebut menafsirkan pengalaman tersebut(Morissan, 2019). Dengan penelitian yang kualitatif-fenomenologi, penulis memaparkan fakta fenomena sosial pengekangan kebebasan beragama di lingkungan sekolah negeri akibat ketiadaan aturan sosial atau hukum yang pasti seperti SKB tiga Menteri yang dicabut oleh Mahkamah Agung. Dan hasilnya adalah memberikan pertimbangan etis Kristen kepada pemerintah pusat dan masyarakat umum serta khususnya kepada umat Kristen dalam menyikapi pencabutan SKB tiga Menteri oleh Mahkamah Agung.

\section{HASIL DAN PEMBAHASAN}

\section{Otonomi Daerah dan Intoleransi}

Sejak selesainya rezim Orde Baru, tahun 1998 Indonesia memasuki masa reformasi. Salah satu ciri khas masa reformasi adalah desentralisasi daerah. Amandemen Pasal 18 UUD 1945 dilakukan untuk menjadi payung hukum terhadap desentralisasi dan otonomi daerah(Unifikasi, 2015, p. 86). Kemudian pemerintah pusat menerbitkan Undang-Undang Nomor 22 Tahun 1999, Undang-Undang Nomor 32 Tahun 2004, Undang-Undang Nomor 6 Tahun 2014 dan Undang- 
Undang Nomor 23 Tahun 2014. Dengan adanya seluruh produk undang-undang tersebut, maka seluruh pemerintah daerah memiliki keleluasaan untuk menciptakan peraturan daerah yang sesuai dengan aspek normatif seperti kebudayaan dan agama mayoritas di wilayahnya masing-masing(D. Olga Pelleng, 2016, p. 75). Salah satu produk peraturan daerah yaitu mengelola sekolah negeri dari tingkat dasar sampai menengah atas tertuang di dalam pasal 10, 11, dan 12 Undang-Undang Nomor 23 Tahun 2014 tentang Pemerintah Daerah. Di dalam pasal 10, pemerintah daerah dapat melaksanakan pemerintahan absolut yang dilimpahkan oleh pemerintah pusat yang salah satunya adalah bidang agama, dan di dalam pasal 11 dan 12 pemerintah daerah menerima pemerintahan absolut untuk melaksanakan pelayanan dasar yang salah satunya adalah pendidikan(Hsb, 2019, p. 5). Peraturan pemerintah daerah mengenai pelaksanaan pendidikan tersebut berjalan bersamaan dengan Permendikbud No 45/2014 mengenai Pakaian Seragam Sekolah Bagi Peserta Didik Jenjang Pendidikan Dasar dan Menengah.

Alhasil dari setiap provinsi di Indonesia yang dijalankan pemerintah daerah memiliki ciri khas di dalam pengelolaan sekolah negeri. Dan sekali lagi ciri khas tersebut tidak dapat dipisahkan dari budaya maupun agama yang ada di daerah yang dipimpin. Dari data statistik Sensus Penduduk tahun 2000 dan 2010 dari Badan Pusat Statistik (BPS) ditemukan pemetaan pertumbuhan keagamaan di Indonesia(Persekutuan Gereja-Gereja di Indonesia, 2021). Berikut data pemetaannya: Pertama Islam, dengan data 87 persen dari total populasi nasional sebanyak 207 juta jiwa. Konsentrasi di pulau Jawa dan Sumatera sebanyak 84 persen. Pertumbuhan secara nasional sebanyak 1,56 persen. Rata-rata pertumbuhan tertinggi dari segi kawasan yaitu di Indonesia timur (Maluku dan Papua) sebanyak 4 persen dan pertumbuhan terendah di kawasan pulau Jawa sebesar 1.17 persen. Rata-rata pertumbuhan tertinggi secara provinsi yaitu di Bali sebanyak 4,85 persen (bertambah 200 ribu jiwa), dan terendah di Sulawesi Selatan 0,34 persen. Dan struktur dari agama Islam di Indonesia adalah umur muda. Kedua, Kristen dengan data 7 persen dari total populasi nasional sebanyak 16,5 juta jiwa. Konsentrasi merata di wilayah Sumatera Utara, Papua dan Sulawesi Utara. Pertumbuhan nasional sebesar 3,41 persen. Pertumbuhan tertinggi dari segi yaitu Indonesia bagian timur yaitu di Maluku dan Papua sebesar 7,03 persen, dan terendah di kawasan Sumatera sebesar 2,51 persen(Persekutuan Gereja-Gereja di Indonesia, 2021).

Pertumbuhan tertinggi dari segi provinsi yaitu Maluku Utara sebesar 10,7 persen, dan terendah di Sulawesi Utara sebesar 1,25 persen. Struktur dari agama Kristen adalah umur muda. Ketiga, Katolik Roma dengan data 2,91 persen dari total populasi nasional sebesar 6,9 juta jiwa. 
Secara merata terkonsentrasi di wilayah Bali dan Nusa Tenggara Timur. Dilihat dari pertumbuhan secara nasional sebesar 1,19 persen. Pertumbuhan tertinggi dari segi kawasan adalah di Indonesia bagian timur yaitu Maluku dan Papua sebesar 6,39 persen, dan terendah di kawasan Sumatera sebanyak -0,65 persen. Pertambahan tertinggi dari segi provinsi yaitu di Papua sebesar 6,58 persen dan terendah di Gorontalo sebesar -6,64 persen. Dan struktur dari Katolik Roma adalah berusia muda(Persekutuan Gereja-Gereja di Indonesia, 2021). Keempat, Hindu dengan data 1,69 persen dari total populasi nasional sebesar 4 juta jiwa. Konsentrasi di wilayah Bali dan Nusa Tenggara Barat sebanyak 84 persen. Pertumbuhan nasional sebanyak 0,95 persen. Pertumbuhan tertinggi di kawasan Indonesia timur yaitu Maluku dan Papua sebanyak 3,05 persen, dan terendah di kawasan Kalimantan sebesar -14 persen. Pertumbuhan di segi provinsi, tertinggi di Gorontalo sebesar 7,3 persen dan terendah di Kalimantan Tengah sebesar -22,5 persen. Dan struktur penganut yaitu umur dewasa(Persekutuan Gereja-Gereja di Indonesia, 2021). Kelima, Budha. Penganut Budha berjumlah 0,72 persen dari populasi nasional atau 1,7 juta jiwa dengan mencatatkan pertumbuhan 9 ribu jiwa dalam waktu 10 tahun. Secara merata berada di wilayah Indonesia bagian barat. Pertumbuhan secara nasional sebesar 0,05 persen, dengan tertinggi secara kawasan di kawasan Indonesia Timur (Maluku-Papua) sebanyak 3,35 persen, dan terendah di Sulawesi sekitar -0,42 persen. Pertumbuhan tertinggi secara provinsi yaitu di Banten sebanyak 3,4 persen dan terendah di Riau sebanyak -5,38 persen. Struktur usia penganut yaitu umur dewasa. Keenam adalah Konghucu. Penganut agama Konghucu sebesar 0,05 persen dari seluruh populasi nasional atau sebanyak 117 ribu jiwa. Konsentrasi penyebaran berada di Jawa, Sumatera khususnya Bangk Belitung sebanyak 43,4 persen, Kalimantan Barat sebanyak 25,4 persen, dan Jawa Barat sebanyak 12,6 persen(Persekutuan Gereja-Gereja di Indonesia, 2021).

Dari data persebaran dan pemetaan keenam agama itu, sudah sangat terlihat bahwa dengan adanya desentralisasi daerah dengan seluruh undang-undang pendukungnya dan ditambah dengan Permendikbud No 45/2014, maka problematika intoleransi agama dalam hal ini kebebasan mengekspresikan keyakinan agama di lingkungan sekolah sangat rentan untuk terjadi di seluruh wilayah Indonesia. Dan itu terbukti dengan catatan Perhimpunan Pendidikan dan Guru (P2G). Menurut catatan P2G telah terjadi beberapa tindakan intoleransi agama di lingkungan sekolah berhubungan dengan penggunaan atribut seragam sekolah yang notabene tidak lepas dari peraturan yang dibuat pemerintah daerah maupun sekolah negeri itu sendiri. Tercatat oleh P2G bahwa tindakan intoleransi beragama berkaitan seragam terjadi di pulau Bali(Andi Saputra, 2021). Catatan 
itu diperkuat dengan temuan Drs. Maneger Nasution dari Komnas HAM Republik Indonesia bahwa hampir di seluruh pulau Bali terjadi pelarangan penggunaan jilbab di sekolah negeri(Ahmad Baraas, 2014). Beberapa temuannya antara lain di SMAN 5 Denpasar dimana di papan pengumuman sekolah dituliskan bahwa siswa dilarang menggunakan penutup kepala. Masih di kota Denpasar, pelarangan penggunaan jilbab juga terjadi di SMAN 2. Selanjutnya di luar kota Denpasar, yaitu di SMPN 1 Singaraja pelarangan penggunaan jilbab tertulis di buku saku siswa di mana bertuliskan bahwa khusus siswa perempuan dilarang menggunakan jilbab(Ahmad Baraas, 2014).

Selain di pulau Bali, P2G mencatat kejadian yang serupa di pulau Flores tepatnya di SMAN 1 Maumere, kabupaten Sikka, Nusa Tenggara Timur(pwmu, 2017). Menurut Staf Khusus bidang Komunikasi Mendikbud, Nasrullah, M. Si, alasan pelarangan karena sekolah kesalahan tafsir aturan seragam sekolah di dalam Permendikbud No 45/2014. Kasus selanjutnya terjadi di tahun 2019, dimana Kepala Perwakilan Ombudsman Papua Barat Musa Sombuk bertemu dengan Kepala SD Inpres 22 Wosi Kabupaten Manokwari berkaitan pelarangan hijab kepada siswa perempuan di sekolah tersebut(Asisten Ombudsman Papua Barat, 2019). Alasan pelarangan karena peraturan pelarangan tersebut dibuat oleh kepala sekolah sebelumnya. Setelah itu tercatat tindakan intoleransi beragama terkait seragam terjadi di SMKN 2 Padang, provinsi Sumatera Barat, dimana siswa non muslim diminta untuk berhijab. Setelah ditelusuri, permintaan berhijab ini merupakan peraturan sekolah. Bahkan menurut mantan Wali Kota Padang, Fauzi Bahar, aturan untuk siswa perempuan berhijab sudah ada sejak 15 tahun yang lalu(Jeka Kampai, 2021). Aturan tersebut tertuang di dalam Instruksi Walikota Padang No.451.442/BINSOS-iii/2005, yang dimana salah satu instruksinya adalah mewajibkan bagi siswa perempuan menggunakan jilbab yang menempuh pendidikan di sekolah negeri di kota Padang(Kampai, 2021).

Dari seluruh catatan P2G termasuk kejadian terbaru di SMKN 2 Padang yang terbuka di awal tahun 2021, dapat terlihat adanya fenomena gunung es berkaitan dengan intoleransi beragama di lingkungan sekolah negeri di seluruh Indonesia(Inas Widyanuratikah, 2021). Semua rentetan kejadian atau fakta di atas menunjukan betapa Indonesia sangat rentan dengan masalah intoleransi beragama dan sangat disayangkan terjadi di lingkungan sekolah negeri yang diselenggarakan pemerintah dalam hal ini pemerintah daerah. Guna mengatasi masalah tersebut, pemerintah nasional melalui tiga kementerian yaitu Menteri Pendidikan dan Kebudayaan, Menteri Dalam Negeri, dan Menteri Agama mengeluarkan Surat Keputusan Bersama (SKB) Nomor 02/KB/2021, 
Nomor 025-199 Tahun 2021, Nomor 219 Tahun 2021 tentang Penggunaan Pakaian Seragam dan Atribut bagi Peserta Didik, Pendidik, dan Tenaga Kependidikan di Lingkungan Sekolah yang Diselenggarakan Pemda pada Jenjang Pendidikan Dasar dan Menengah. Maksud dari SKB ini adalah mewajibkan pemerintah daerah serta kepada sekolah mencabut aturan yang mewajibkan atau melarang penggunaan seragam dengan kekhususan agama(Marlinda Oktavia Erwanti, 2021). Salah satu penerapan di lapangan dalam beberapa poin yang di dalam SKB tersebut adalah murid dan guru berhak memilih seragam yang dikenakan(Tim Detikcom, 2021).

Keputusan tiga menteri untuk mengeluarkan SKB tersebut merupakan langkah yang tepat sesuai undang-undang karena sifat pemerintahan Indonesia adalah Negara Kesatuan Republik Indonesia walaupun di satu sisi Indonesia menganut pemerintahan yang terdesentralisasi di daerah. Makna dari Negara Kesatuan Republik Indonesia adalah negara Republik Indonesia yang dimana pemerintah pusat atau nasional memegang kedudukan tertinggi, dan memiliki kekuasaan penuh dalam pemerintahan sehari-hari(Reynold Simandjuntak, 2015, p. 58). Sebagai perpanjangan tangan pemerintah pusat, SKB tiga menteri yang dikeluarkan tersebut tidak bertentangan dengan sistem pemerintahan yang ada saat ini. Selain itu pemerintah pusat memiliki alasan politik hukum pemerintahan. Politik hukum pemerintahan yang dimaksud adalah pertama sebagai suatu pernyataan kehendak pemerintah negara atau pusat tentang hukum yang dimana berlaku di seluruh wilayahnya dan kedua mengenai tujuan perkembangan hukum yang dibangun(Agus Kusnadi, 2015, p. 568). Sangat jelas bahwa arah politik pemerintahan Negara Kesatuan Republik Indonesia terkandung di dalam Pancasila. Pancasila adalah falsafah kenegaraan atau cita-cita negara yang berfungsi sebagai common platform atau kalimatun sawa di antara sesama warga masyarakat dalam konteks kehidupan berbangsa dan bernegara (Jimly Asshiddiqie, n.d., p. 6). Pancasila sebagai dasar falsafah negara memiliki salah satu tujuan membentuk rakyat Indonesia sebagai bangsa dan negara yang berbudaya dalam beragama.

Jika dilihat dengan berbagai latar belakang kejadian intoleransi beragama yang terjadi di lingkungan sekolah negeri maka maksud pemerintah pusat yang diwakilkan tiga menteri dalam penerbitan SKB tiga menteri adalah sangat tepat karena untuk mencegah intoleransi agama terus terjadi di lingkungan sekolah negeri yang dimana di lingkungan tersebut manusia Indonesia dibentuk untuk berbudaya di dalam keberagaman agama atau keyakinan. SKB tiga Menteri tersebut merupakan tindakan tepat dari pemerintah untuk memberikan peraturan sosial yang mengikat secara hukum di dalam kebebasan mengekspresikan agama yang dianut dengan atribut seragam di 
sekolah yang diselenggarakan oleh pemerintah. Hal tersebut senada dengan pernyataan Menteri Dalam Negeri Tito Karnavian bahwa sekolah memiliki peran yang penting dan bertanggung jawab di dalam menjaga keberadaan ideologi dan konsensus negara yaitu Pancasila, UUD 1945, NKRI, dan Bhineka Tunggal Ika(Yulida Medistiara, 2021). Namun pada tanggal 3 Mei 2021 dengan perkara nomor 17/P/HUM/2021, Mahkamah Agung memutuskan untuk mencabut SKB tiga menteri yang diterbitkan pada 3 Februari 2021. Dalam proses pengambilan keputusan untuk mencabut SKB tiga Menteri, Mahkamah Agung memakai produk-produk hukum yang sudah ada seperti Pasal 10, Pasal 11, dan Pasal 12 Undang-Undang Nomor 23 Tahun 2014 tentang Pemerintahan Daerah, Pasal 1 angka 1 Undang-Undang Nomor 35 tahun 2014 tentang Perubahan Atas Undang-Undang Nomor 23 tahun 2002 tentang Perlindungan Anak, Pasal 1 angka 1 dan 2 Undang-Undang No 12 Tahun 2011 tentang Pembentukan Peraturan Perundang-undangan, Pasal 1 angka 1 dan angka 2, Pasal 3, dan Pasal 12 ayat (1) huruf a Undang-Undang Nomor 20 Tahun 2003 tentang Sistem Pendidikan Nasional(Permana, 2021).

Dengan keputusan pencabutan dari Mahkamah Agung terhadap SKB tiga Menteri, maka seluruh peraturan di dalam SKB tiga Menteri tersebut harus dicabut dan tidak berlaku di seluruh wilayah Republik Indonesia(Makki, 2021). Dengan demikian, Pasal 10, Pasal 11, dan Pasal 12 Undang-Undang Nomor 23 Tahun 2014 tentang Pemerintahan Daerah, Pasal 1 angka 1 UndangUndang Nomor 35 tahun 2014 tentang Perubahan Atas Undang-Undang Nomor 23 tahun 2002 tentang Perlindungan Anak, Pasal 1 angka 1 dan 2 Undang-Undang No 12 Tahun 2011 tentang Pembentukan Peraturan Perundang-undangan, Pasal 1 angka 1 dan angka 2, Pasal 3, dan Pasal 12 ayat (1) huruf a Undang-Undang Nomor 20 Tahun 2003 tentang Sistem Pendidikan Nasional dan Permendikbud No 45/2014 tetap berlaku sebagai payung hukum untuk menjalankan sekolah negeri yang diselenggarakan oleh pemerintah daerah(Makki, 2021). Pencabutan SKB tiga Menteri yang diputuskan Mahkamah Agung memberikan peringatan bahwa masih akan terjadi lagi tindakan intoleransi agama di lingkungan sekolah negeri. Beberapa pihak yang menyesalkan pencabutan ini adalah KPAI (Komisi Perlindungan Anak Indonesia). Penyesalan ini beralasan karena SKB tiga Menteri sudah sejalan dengan HAM dan sejalan dengan UU No 35 Tahun 2014 tentang Perlindungan Anak(Detikcom, 2021). KPAI mencatat bahwa akibat tidak menggunakan jilbab, siswi di SMA Negeri 1 Gemolong, Sragen(CNN Indonesia, 2021), Jawa Tengah, mengalami teror dan bully. Akibatnya siswi tersebut merencanakan untuk bunuh diri. Peristiwa ini membuktikan bahwa intoleransi agama di sekolah berdampak pada masalah psikologis dan sosial dari peserta 
didik dalam hal ini usia muda yang masih dikategorikan anak-anak. Dengan ketiadaan SKB tiga menteri yang dicabut oleh Mahkamah Agama, masyarakat diperhadapkan pada konflik horizontal. Konflik horisontal ini berhubungan dengan pelanggaran hak asasi manusia khususnya kebebasan beragama. Disebut pelanggaran hak asasi manusia karena dari berbagai catatan yang diterima dan direkam oleh P2G dan KPAI telah terjadi pelarangan untuk melaksanakan keyakinan agama yang dianutnya dan pemaksaan untuk menjalankan keyakinan agama yang tidak diyakininya. Negara sebagai penyedia dan penyelenggara sekolah negeri harus mencegah intoleransi beragama yang dapat terus berlangsung.

Dari sudut masyarakat internasional, Indonesia yang bergabung sebagai anggota Perserikatan Bangsa-Bangsa (PBB) telah meratifikasi Kovenan HAM Internasional yang dimana diatur di dalam Pasal 11 UndangUndang Dasar 1945, Surat Presiden RI Nomor: 2826/HK/1960 dan Undang-Undang Nomor 24 Tahun 2000 tentang Perjanjian Internasional. Dalam bidang Hak Asasi Manusia (HAM), Indonesia telah meratifikasi dua Kovenan HAM Internasional yang dimana dua kovenan itu adalah pertama Kovenan Internasional tentang hak-hak ekonomi, sosial, dan budaya yang diratifikasi menjadi Undang-Undang Nomor 11 Tahun 2005. Dan kedua Kovenan Internasional tentang hak-hak sipil dan politik yang diratifikasi oleh Indonesia menjadi UndangUndang Nomor 12 Tahun 2005(Kovenan \& Internasional, 2017, p. 1). Menurut KBBI ratifikasi adalah pengesahan suatu dokumen negara oleh parlemen, khususnya pengesahan undang-undang, perjanjian antar negara, dan persetujuan hukum internasional (Kamus Besar Bahasa Indonesia (KBBI), 2021). Tindakan intoleransi agama di lingkungan sekolah yang terjadi sebelum adanya SKB tiga Menteri dan sesudah dicabutnya SKB tersebut dapat terindikasi pelanggaran HAM. Di mana siswa didik dilarang menjalankan kewajiban agama yang diyakini atau memaksa siswa yang didik menjalankan kewajiban agama yang tidak diyakininya. Salah satu kovenan PBB mengenai HAM yang diratifikasi oleh Indonesia berbunyi "semua orang berhak atas semua hak dan kebebasan yang diatur dalam deklarasi, tanpa pembedaan apa pun, seperti ras, warna kulit, jenis kelamin, bahasa, agama, pandangan politik atau pendapat lainnya, asal usul kebangsaan atau sosial, kekayaan, kelahiran atau status lainnya” (Undang-Undang Hak Internasional pasal 2)(Stott, 2015, p. 217). Dari sudut pandang Hak Asasi Manusia, SKB tiga Menteri yang dicabut oleh Mahkamah Agung sebenarnya sangat sejalan dengan HAM dan Undang-Undang Hak Internasional yang diratifikasi oleh Indonesia. 


\section{Sikap Etis Kristen}

Manusia diciptakan menurut gambar dan rupa Allah dan Allah adalah satu-satunya pemberi kehidupan kepada manusia seperti yang dinyatakan Alkitab di dalam Kejadian 1:26-27 dan Kejadian 2:7. Ini adalah dasar etis Kristen mengenai siapakah itu manusia yang menjunjung tinggi kehidupan yang dari Allah. Manusia tidak diciptakan Allah dalam rupa makhluk mana pun yang telah diciptakan Allah sebelum manusia, namun diciptakan dalam rupa TUHAN(Henry, 2014, p. 27). Di dalam Kejadian 1:26, dituliskan Berfirmanlah Allah: "Baiklah Kita menjadikan manusia menurut gambar dan rupa Kita ". Ini adalah pernyataan tegas mengenai arti manusia sejati atau manusia seutuhnya. Di dalam kalimat "Baiklah Kita menjadikan manusia menurut gambar dan rupa Kita" memiliki makna yang dalam mengenai arti dan nilai manusia yang diciptakan olah TUHAN. Makna yang pertama bahwa ide penciptaan manusia berasal dari Allah sendiri. Sehingga nilai manusia ditentukan oleh Allah sang Pencipta. Di mana Allah yang Tritunggal, yaitu satu Allah dengan tiga pribadi berbeda, menciptakan manusia. Tiga pribadi tersebut memiliki nilai yang sama dan begitupun derajat-Nya, dengan demikian setiap pribadi adalah sama dalam substansi, setara dalam kuasa dan kemuliaan(Boice, 2015). Berbeda dengan penciptaan makhluk hidup dan benda lainnya, penciptaan manusia sungguh istimewa karena khusus di dalam penciptaan manusia Allah menyatakan siapakah Dia yang adalah Tritunggal yang Esa. Di dalam ketritunggalan itu ada keharmonisan hubungan. Dengan demikian maka Alkitab hendak memberikan makna bahwa manusia yang berasal dari inisiatif Allah memiliki hubungan pribadi dengan Allah, sebagaimana Ia adalah pribadi yang berhubungan di dalam ketritunggalan(Stott, 2015, p. 223). Sebagaiman Allah adalah Tritunggal dalam keharmonisan, demikian juga manusia memiliki hubungan yang harmonis dengan-Nya. Manusia yang bernilai di hadapan Allah, merupakan manusia yang memiliki hubungan harmonis dengan-Nya dan sesama manusia. Hubungan yang tercipta antar manusia adalah hubungan yang sederajat.

Di dalam Kejadian 2:7, dituliskan "ketika itulah TUHAN Allah membentuk manusia itu dari debu tanah dan menghembuskan nafas hidup ke dalam hidungnya; demikianlah manusia itu menjadi mahkluk yang hidup”. Sebagai manusia yang segambar dan serupa dengan Allah, manusia diberikan hidup hanya oleh-Nya. Berbeda dengan makhluk hidup lainnya, khusus manusia, Allah menghembuskan nafas ke dalam hidungnya agar manusia itu hidup. Nafas manusia sungguh bernilai di hadapan Allah. Dengan demikian jiwa manusia menjadi hidup oleh karena nafas dari sorga dan dihasilkan dari Allah(Henry, 2014, p. 42). Dengan demikian kehidupan manusia sangat 
berharga di mata Allah. Kisah penciptaan di dalam Kejadian 2:7 sebenarnya merupakan kisah untuk menjelaskan bagaimana Allah menciptakan manusia yang pertama di dalam Kejadian 1:27. Manusia yang diciptakan TUHAN segambar dengan-Nya, dibentuk menjadi laki-laki dan perempuan. Sehingga laki-laki dan perempuan memiliki kesederajatan di hadapan Allah dan memiliki nafas hidup dari satu sumber yang sama yaitu Allah sendiri. Maka laki-laki dan perempuan memiliki hak yang sama untuk berhubugan dengan Allah sang Penciptanya.

Dengan demikian manusia yang sejati tidak lepas dari hubungan pribadi dengan TUHAN yang adalah pencipta-Nya. Berhubungan pribadi dengan Allah merupakan keistimewaan dari setiap manusia, laki-laki dan perempuan. Martabat manusia juga berasal dari Allah sebagai pencipta dan pemberi kehidupan, sehingga setiap manusia yang bermartabat menghormati hak untuk sesamanya berhubungan dengan Allah dan melakukan hukum Allah sang Pencipta(Stott, 2015, p. 222). Tidak ada satupun manusia dapat melarang manusia; laki-laki atau perempuan untuk memiliki hubungan dengan sang Pencipta. Laki-laki dan perempuan setara dalam hubungan pribadinya kepada TUHAN. Walaupun manusia pertama jatuh dalam dosa di dalam Kejadian 3, namun kejatuhan manusia tersebut tidak mengubah kebenaran bahwa Allah menghendaki manusia berhubungan dengan-Nya, karena berhubungan dengan Allah adalah rencana sedari awal manusia diciptakan-Nya. Sebagai orang Kristen, Roh Kudus yang bekerja di dalam hati mengamini firman Allah yang tertulis di dalam Alkitab termasuk mengenai penciptaan manusia di dalam Kejadian 1 dan 2 termasuk di dalam pasal 3 dan seluruh firman Allah, Alkitab. Di dalam martabat sebagai manusia, manusia diberikan kebebasan oleh Allah. Kewibawaan TUHAN atas manusia yang diciptakan-Nya sebagai makhluk yang memiliki akal dan kehendak bebas(Henry, 2014, p. 52). Namun dengan kehendak bebas itu manusia jatuh dalam dosa. Oleh sebab itu, setelah kejatuhan manusia, kesempurnaan hidup manusia hanya terjadi di dalam iman percaya kepada Tuhan Yesus Kristus. Ia adalah pribadi Putra dalam Allah Tritunggal yang datang ke dalam dunia yang menyatakan kehidupan kekal dari Allah kepada manusia yang jatuh dalam dosa. Tuhan Yesus Kristus datang ke dalam dunia untuk memberikan hidup kekal kepada manusia yang percaya kepada-Nya dan dengan status itu manusia dapat memiliki hubungan pribadi dengan Allah Bapa. Manusia sejati yang diciptakan baru oleh Roh Kudus melalui iman percaya kepada Tuhan Yesus merupakan manusia yang menghargai kehidupan dan hubungan pribadi dengan Allah, khususnya Allah yang dinyatakan di dalam Alkitab. Oleh sebab itu di dalam kehidupan manusia Kristen, manusia dipahami memiliki kebebasan untuk memiliki hubungan pribadi dengan TUHAN dan 
menghidupi hukum Allah yang diyakini-Nya yang dimana itu semua membentuk martabat manusia(Tebay, 2008).

Makna selanjutnya dari Allah menciptakan manusia yaitu bahwa manusia yang seutuhnya adalah manusia yang sederajat di dalam penguasaan alam yang diciptakan oleh Allah. Di dalam Kejadian 1:26 dan 28 dituliskan secara berulang bahwa manusia, yaitu laki-laki dan manusia berkuasa atas ciptaan lain dan juga berkuasa menaklukan itu semua. Salah satu cara penguasaan atas ciptaan tersebut menggunakan sarana, yaitu pengetahuan yang diperoleh melalui pendidikan yang dimana pendidikan merupakan bagian dari kebudayaan. Mavies dan John Biesanz mengatakan bahwa alamat penyelamat kemanusiaan di muka bumi adalah kebudayaan(Jujun S. Suriasumantri, 2009, p. 262). Di masa modern ini, manusia yang seutuhnya memiliki akses bebas ke dunia pendidikan dengan bebas. Ini dikarenakan laki-laki dan perempuan secara universal memiliki kesamaan hak untuk memperoleh pendidikan sebagai wujud menjalankan perintah Allah untuk menguasai dan menaklukan ciptaan-Nya yang lain(M. S. Sumantri, 2015). Di masa ini pengetahuan yang utuh tersebut diperoleh sejak usia dini di lingkungan pendidikan yaitu sekolah dasar sampai menengah atas yang dimana dalam proses memperolehnya harus memperhatikan individualitas atau karakteristik perbedaan antar individu(M. \& U. S. S. Sumantri, 2003). Dengan demikian pendidikan yang dijalani peserta didik harus dalam suasana kebebasan beragama di sekolah, kebebasan itu terwujud dengan kebebasan bagi anak didik maupun pendidik untuk menggunakan atau tidak menggunakan atribut seragam yang sesuai dengan agama yang diyakini ataupun menolak menggunakan atribut seragam yang tidak diyakini.

Alkitab menjunjung kebebasan, bahkan kebebasan beragama. Alkitab menuliskan sisi humanis dari manusia, yang dimana sisi humanis manusia memperlihatkan keunikan dan keindahan manusia yang adalah ciptaan Allah yang bermatabat(Kadarmanto, 2018). Salah satu sisi humanis yang dinyatakan dalam Alitab adalah dalam Yosua 24:15 dimana mereka secara individu diberikan kesempatan untuk memilih apakah beribadah kepada TUHAN atau beribadah kepada allah yang disembah oleh bangsa-bangsa yang ditaklukan oleh mereka walaupun mereka dengan mata kepada sendiri telah mengalami perbuatan ajaib dari TUHAN Allah Israel. Yosua 24:15 berbunyi “'Tetapi jika kamu anggap tidak baik untuk beribadah kepada TUHAN, pilihlah pada hari ini kepada siapa kamu akan beribadah; allah yang kepadanya nenek moyangmu beribadah di seberang sungai Efrat, atau allah orang Amori yang negerinya kamu diami ini. Tetapi aku dan seisi rumahku, kami akan beribadah kepada TUHAN!” Penulis kitab Yosua, menuliskan untuk setiap 
individu bangsa Israel diberikan kebebasan memilih kepada siapa mereka percaya dan siapa yang mereka layani, apakah TUHAN yang hidup atau allah yang mati. Yosua begitu menitik beratkan kepada kehendak bebas(Dan G. Kent, 1980, p. 81). Sebagai pemimpin bangsa Israel, Yosua memilih beribadah kepada TUHAN Allah Israel dan menyerahkan keputusan individu dengan bebas untuk menyembah siapa yang hendak mereka sembah. Mereka memilih pilihan bebas untuk menolak kovenan yang diikat oleh TUHAN dengan nenek moyang mereka(Dan G. Kent, 1980, p. 81). Keputusan individu dari Yosua dan keluarganya bukanlah paksaan demikian juga individu yang lain di tengah-tengah bangsa Israel. Yosua meyakini bahwa hanya Allah Israel adalah TUHAN, dan ia memutuskan untuk beribadah kepada-Nya. Sangat terlihat bahwa ada kebebasan memilih bagi orang Israel untuk mengikuti Allah Israel atau allah bangsa-bangsa sekitar mereka di tanah Kanaan. Kebebasan bagi setiap individu Israel untuk memilih mengikuti Allah atau allah bangsa lain tidak menghilangkan fakta bahwa Allah Israel adalah satu-satunya TUHAN yang hidup dan benar(Lumingkewas, 1971).

Dari fakta Alkitab tersebut, jelas kebebasan diberikan Allah kepada setiap individu. Manusia seutuhnya yang diciptakan oleh Allah diberikan kehendak bebas. Di dalam Pengakuan Iman Baptis 1689 dituliskan bahwa secara alamiah Allah memperlengkapi manusia dengan kehendak bebas dan kuasa untuk bertindak menurut pilihannya sendiri. Kehendak dan pilihan manusia tidak dipaksa baik dari luar maupun dari dalam untuk berbuat baik atau jahat (Pasal 9. Kehendak Bebas)(Pengakuan Iman Baptist 1689, n.d.). Di dalam kehidupan manusia yang diberikan kehendak bebas, manusia memiliki hati nurani di mana Allah sendiri adalah Tuhan atas hati nurani(Pengakuan Iman Baptist 1689, n.d.). Dengan demikian iman yang sejati dan murni kepada TUHAN lahir di tengah-tengah kehendak bebas individu manusia dan di dalam hati nurani yang melawan dosa yang mengikatnya akibat kejatuhan manusia pertama. Iman kepada TUHAN yang dinyatakan dalam Alkitab adalah hasil pekerjaan Allah Roh Kudus di dalam hati nurani dan di tengah-tengah sifat dasar manusia yang memiliki kehendak bebas. Kebebasan dalam status memiliki kehendak bebas bukan berarti manusia bebas melakukan apapun yang diinginkan hatinya. Manusia secara universal masih terikat dengan hukum moral dari Allah di hati nuraninya sebagaimana manusia diciptakan oleh Allah dan memiliki nafas dari-Nya.

Setiap orang Kristen memiliki peran untuk menyetujui kebebasan beragama dimanapun keberadaannya di wilayah Indonesia. Hukum moral Allah yang dipercayai setiap orang Kristen pada hakekatnya berlaku universal. Dunia pendidikan Indonesia tidak dapat dilepaskan dari UUD 
1945, NKRI, Pancasila dan Bhineka Tunggal Ika. Seluruh hukum yang terkandung di dalam itu semua sangat sejalan dengan hukum moral TUHAN yang universal di dalam Alkitab. Status manusia seutuhnya yang diciptakan Allah seperti yang tertulis di dalam Kejadian 1:26-28 tidak hanya berlaku untuk setiap orang Kristen, namun juga kepada semua manusia yang diciptakan oleh Allah. Ha itu adalah keniscayaan karena setiap manusia tidak dijadikan dalam rupa makhluk apapun yang telah diciptakan oleh Allah sebelumnya, namun dalam rupa Tuhan sang Pencipta(Henry, 2014, p. 27). Intoleransi beragama di lingkungan sekolah dengan pemaksaan penggunaan atribut agama yang tidak diyakini maupun pemaksaan untuk tidak memakai atribut agama yang diyakini merupakan tindakan di luar hukum moral yang bersifat universal.

Sebagai negara yang telah meratifikasi Kovenan HAM Internasional. Pemerintah wajib menghadirkan nilai keutuhan manusia dan moral universal di tengah-tengah sekolah yang dikelolanya. Mayoritas agama di suatu provinsi tidak dapat merasuk lingkungan sekolah untuk menekan penganut minoritas dengan menetapkan atribut seragam yang sesuai dengan agama mayoritas. SKB tiga Menteri yang diterbitkan bulan Februari 2021 seyogya adalah aturan agar terjadi tertib kehidupan beragama di lingkungan sekolah. Pencabutan SKB tiga Menteri tersebut oleh Mahkamah Agung menjadikan pemerintah harus bertanggung jawab untuk menghadirkan lagi aturan hukum agar moral universal kebebasan beragama secara individu di sekolah yang dikelola pemerintah agar terlaksana dengan baik pendidikan yang bermartabat sebagaimana diamanatkan di dalam UUD 1945 dan Pancasila dengan semboyan Bhineka Tunggal Ika. Sebab sejatinya pemerintah harus menghadirkan kesejahteraan dan juga keamanan dalam kerukunan umat beragama. Sehingga perpecahan atau kerukunan yang terganggu dapat diminimalisasi (Arifianto \& Santo, 2020).

Kebebasan beragama di lingkungan sekolah yang dikelola oleh negara dalam hal ini pemerintah daerah harus mendukung hukum moral yang universal kepada setiap individu di lingkungan sekolah yaitu peserta didik dan pendidik. Pelarangan pemakaian jilbab sebagai atribut seragam atau pemaksaan pemakaian jilbab sebagai atribut seragam termasuk intoleransi beragama. Kehadiran SKB tiga Menteri yang seyogya meniadakan pemaksaan berhubungan dengan atribut seragam sekolah sangat mendukung hukum moral yang universal. Keputusan Mahkamah Agung sebenarnya masih dapat ditanggapi dengan PK (Peninjauan Keputusan) oleh tiga kementerian penerbit SKB tersebut di Mahkamah Konstitusi. Namun selama keputusan Mahkamah Konstitusi belum terbit orang Kristen harus bersikap. 
Sikap persuasif dan transformatif, itulah yang menjadi sikap etis Kristen dalam menyikapi problematika ini, yang dimana sikap ini memiliki misi untuk menciptakan kebersamaan dengan semua orang karena semua manusia diciptakan segambar dengan Allah(Sudarmanto, 2020). Dalam sikap persuasif dan transformatif lahir sikap menghargai dan menghormati sesama manusia yang dimana sikap itu mengemban amanat budaya dari Tuhan(Sudarmanto, 2020). Dengan demikian Etika Kristen dilandasi kepada pengertian bahwa Alkitab adalah satu-satunya hukum tertinggi dalam kehidupan iman dan sebagai warga negara Indonesia, UUD 1945 dan Pancasila adalah hukum absolut tertinggi dalam berbangsa dan bernegara. Sikap yang transformatif dan persuasif akan menjunjung kebebasan beragama di lingkungan sekolah negeri dalam hal ini menolak pemaksaan penggunaan hijab bagi non muslim dan menolak pelarangan penggunaan hijab di sekolah. Hukum moral Allah yang universal dijalankan di dalam kehidupan walaupun berada di wilayah mayoritas maupun minoritas agama Kristen. Namun ada resiko dengan sikap etis Kristen yang persuasif dan transformatif yaitu pergolakan dengan pihak sekolah, organisasi masyarakat atau pemerintah daerah yang memutuskan peraturan yang berpihak pada agama mayoritas di daerah dimana sekolah negeri tersebut berada. Secara tegas sikap persuasif dan transformatif ini menyatakan bahwa intoleransi beragama adalah salah, dan peraturan sekolah atau peraturan pemerintah yang memaksakan pemakaian hijab atau yang melarang penggunaan hijab adalah salah. Sikap etika Kristen yang persuasif dan transformatif didasarkan pada kenyataan dan fakta bahwa siapapun manusia sederajat di hadapan Allah dan semua manusia diciptakan dengan kehendak bebas. Sikap persuasif dan transformatif etika Kristen menolak intoleransi agama dan mendukung sekolah negeri memberikan kebebasan beragama kepada peserta didik untuk menggunakan atau tidak menggunakan atribut seragam yang sesuai atau tidak sesuai agama yang diyakini. Dengan tegas etika Kristen mendukung hukum moral universal. Dan Pancasila dengan semboyan Bhineka Tunggal Ika mengandung hukum moral universal. Sehingga memunculkan sikap kerukunan yang tercipta dapat memudahkan komunikasi dan terlebih menghasilkan kerja sama yang dapat mempererat kesatuan dan persatuan bangsa (Arifianto, 2021).

\section{KESIMPULAN}

UUD 1945 dan Pancasila sebagai hukum absolut tertinggi di Indonesia harus ditegakkan dan diterapkan oleh seluruh pemerintah daerah demi menghadirkan kehidupan masyarakat Indonesia yang bermartabat dan teratur. Oleh sebab itu etis Kristen menyikapi penghapusan SKB 
tiga Menteri adalah melindungi hak siswa Muslimah yang mengambil keputusan berhijab untuk dapat menggunakannya di lingkungan sekolah negeri yang mayoritas non Muslim, dan bagi siswa yang non Muslim atau beragama bukan Islam, harus dilindungi haknya untuk tidak dipaksa memakai atribut Muslim di tengah-tengah sekolah negeri yang mayoritas Muslim. Setiap peserta didik dan pendidik harus bebas untuk menjalankan dan mengekspresikan keyakinan agama yang diyakininya dengan kebebasan yang berdasarkan hukum moral yang universal yang terkandung dalam Pancasila. Pancasila dengan semboyan Bhineka Tunggal Ika harus diterapkan secara tegas dan humanis oleh pemerintah pusat dan daerah beserta seluruh insan yang hidup di Indonesia. Sikap etis Kristen yang transformatif sejalan dengan hukum moral yang universal yang terkandung didalam Pancasila yang adalah fondasi bangsa dan Negara Kesatuan Republik Indonesia. Etis Kristen sebagai warga negara Indonesia adalah tunduk pada hukum absolut yaitu firman Allah dan di dalam kehidupan bernegara tunduk pada hukum absolut negara yang berdasarkan Pancasila dan UUD 1945.

\section{REFERENSI}

Agus Kusnadi. (2015). Perkembangan Politik Hukum Pemerintahan Desa Menurut UndangUndang Nomor 32 Tahun 2004 tentang Pemerintahan Daerah dan Undang-Undang Nomor 6 Tahun 2014 tentang Desa. PADJADJARAN Jurnal Ilmu Hukum, 2(3), 568.

Ahmad Baraas. (2014). Komnas HAM: Pelarangan Jilbab Terjadi Hampir di Seluruh Bali. Republika.Co.Id. https://republika.co.id/berita/nasional/daerah/14/02/21/n1c9xr-komnasham-pelarangan-jilbab-terjadi-hampir-di-seluruh-bali

Andi Saputra. (2021). Alasan MA Perintahkan Mendikbud-Mendagri-Menag Cabut SKB Seragam Sekolah. DetikNews. https://news.detik.com/berita/d-5561762/alasan-maperintahkan-mendikbud-mendagri-menag-cabut-skb-seragamsekolah?_ga=2.8708661.124097271.1621089402-635142967.1611418912

Arifianto, Y. A. (2021). Menumbuhkan Sikap Kerukunan dalam Perspektif Iman Kristen Sebagai Upaya Deradikalisasi. Khazanah Theologia, 3(2), 93-104.

Arifianto, Y. A., \& Santo, J. C. (2020). Tinjauan Trilogi Kerukunan Umat Beragama Berdasarkan Perspektif Iman Kristen. Angelion, 1(1), 1-14.

Asisten Ombudsman Papua Barat. (2019). Larangan Penggunaan Hijab pada SD Inpres 22 Wosi Manokwari, Ombudsman temui Kepala Sekolah. Https://Ombudsman.Go.Id/. 
https://ombudsman.go.id/artikel/r/artikel--larangan-penggunaan-hijab-pada-sd-inpres-22wosi-manokwari-ombudsman-temui-kepala-sekolah-

Boice, J. M. (2015). Dasar-dasar Iman Kristen. Momentum.

CNN Indonesia. (2021). Kronologi Siswi Sragen Diteror Karena Tak Berjilbab.

Https://Www.Cnnindonesia.Com/.

https://www.cnnindonesia.com/nasional/20200109213447-20-464063/kronologi-siswisragen-diteror-karena-tak-berjilbab

D. Olga Pelleng. (2016). Peraturan Daerah Sebagai Landasan Penyelenggaraan Pemerintahan Daerah. Lex Et Societatis, 4(3).

Dan G. Kent. (1980). Layman's Bible Book Commentary. Joshua, Judges, Ruth. Broadman Press.

Detikcom, T. (2021). KPAI Sesalkan MA Batalkan SKB 3 Menteri soal Seragam, Ini Alasannya. Https://News.Detik.Com/. https://news.detik.com/berita/d-5562054/kpai-sesalkan-mabatalkan-skb-3-menteri-soal-seragam-inialasannya?_ga=2.119013385.124097271.1621089402-635142967.1611418912

Henry, M. (2014). Tafsiran Matthew Henry. Kitab Kejadian. Momentum.

Hsb, A. M. (2019). Pelaksanaan Kewenangan Atribusi Pemerintahan Daerah Berdasarkan Undang-Undang Nomor 23 Tahun 2014 tentang Pemerintahan Daerah. 1-8. https://doi.org/10.31219/osf.io/utw97

Inas Widyanuratikah. (2021). Menag Sebut Kasus SMKN 2 Padang Hanya Fenomena Gunung Es. Republika.Co.Id. https://www.republika.co.id/berita/qny81w409/menag-sebut-kasussmkn-2-padang-hanya-fenomena-gunung-es

Jeka Kampai. (2021). Eks Walkot Padang: Aturan Siswi Berjilbab Sudah 15 Tahun, Kok Baru Ribut? DetikNews. https://news.detik.com/berita/d-5345873/eks-walkot-padang-aturansiswi-berjilbab-sudah-15-tahun-kok-baru-ribut

Jujun S. Suriasumantri. (2009). Filsafat Ilmu. Pustaka Sinar Harapan.

Kadarmanto, M. (2018). Humanisme, Reformasi Dan Pendidikan Dalam Protestanisme Awal Dan Implementasinya Dalam Mendidik Guru Kristen Di Era Global. https://doi.org/10.31227/osf.io/j9dz8

Kampai, J. (2021). Disdik Sumbar soal Aturan Siswi Berjilbab: Selama Ini Tak Ada Gejolak. Https://News.Detik.Com/. https://news.detik.com/berita/d-5346599/disdik-sumbar-soalaturan-siswi-berjilbab-selama-ini-tak-ada- 
gejolak?_ga=2.46000676.124097271.1621089402-635142967.1611418912

Kamus Besar Bahasa Indonesia (KBBI). (2021). Ratifikasi. Https://Kbbi.Web.Id/. https://kbbi.web.id/ratifikasi

Kovenan, R., \& Internasional, H. A. M. (2017). Praktik Ratifikasi Terhadap Perjanjian Internasional Di Bidang Hak Asasi Manusia. Lex Crimen, 5(4), 135-144.

Lumingkewas, M. S. (1971). Allah Israel.

Makki, S. (2021). MA Batalkan SKB 3 Menteri soal Aturan Seragam Sekolah. CNN Indonesia. https://www.cnnindonesia.com/nasional/20210507123114-12-639912/ma-batalkan-skb-3menteri-soal-aturan-seragam-sekolah

Marlinda Oktavia Erwanti. (2021). SKB 3 Menteri, Nadiem: Sekolah Negeri Harus Cabut Aturan Seragam Khusus Agama. Https://News.Detik.Com/. https://news.detik.com/berita/d5359848/skb-3-menteri-nadiem-sekolah-negeri-harus-cabut-aturan-seragam-khusus-agama Morissan. (2019). Riset Kualitatif (D. Suraya, D. F. Hamid, \& D. E. Bassar (Eds.); Pertama). Prenadamedia Group.

Pengakuan Iman Baptist 1689. (n.d.). Carey Publication.

Permana, R. H. (2021). MA Minta SKB 3 Menteri Dicabut karena Bertentangan UU Ini. Https://News.Detik.Com/. https://news.detik.com/berita/d-5562280/ma-minta-skb-3menteri-dicabut-karena-bertentangan-uu-ini/2

Persekutuan Gereja-Gereja di Indonesia. (2021). Membaca Demografi Agama-agama di Indonesia. Https://Pgi.or.Id/. https://pgi.or.id/membaca-demografi-agama-agama-diindonesia/

Prof. Dr. Jimly Asshiddiqie, S. H. (n.d.). Ideologi, Pancasila, Dan Konstitusi. Mahkamah Konstitusi Republik Indonesia, 23.

pwmu. (2017). Viral SMAN 1 Maumere Larang Siswi Berjilbab, Kemdikbud: Keliru Tafsirkan Permendikbud Seragam Sekolah. Pwmu.Co. https://pwmu.co/36622/09/14/viral-sman-1maumere-larang-siswi-berjilbab-kemdikbud-keliru-tafsirkan-permendikbud-seragamsekolah/

Reynold Simandjuntak. (2015). Sistem Desentralisasi Dalam Negara Kesatuan Republik Indonesia Perspektif Yuridis Konstitusional. De Jure, Jurnal Syariah Dan Hukum, 7(1), 58. Simon, S., \& Arifianto, Y. A. (2021). Kerukunan umat beragama dalam bingkai iman kristen di era disrupsi 1. Literasi: Jurnal Pengabdian Pada Masyarakat Is, 1(1), 35-43. 
Stott, J. (2015). Isu-isu Global (revisi). Yayasan Komunikasi Bina Kasih.

Sudarmanto, G. (2020). Misi Transformatif Di Tengah Tantangan Gereja. 2000, 106-139. https://doi.org/10.31219/osf.io/aysmu

Sumantri, M. \& U. S. S. (2003). Pendidikan dasar dan menengah. Indonesia Dalam Arus Sejarah VIII, 021, 1-39.

Sumantri, M. S. (2015). Modul Hakikat Manusia dan Pendidikan. Pengantar Pendidikan, 1-43. https://www.google.com/url?sa=t\&source=web\&rct=j\&url=http://repository.ut.ac.id/4028/1/ MKDK4001-

M1.pdf\&ved=2ahUKEwia4d2nmoHkAhVKqY8KHfb4BcAQFjAJegQIBxAB\&usg=AOvV aw1JH5ksrCgIlrXdlkYefnAv

Tebay, N. (2008). Kebebasan Beragama dalam Ajaran Paus Yohanes Paulus II. Studia Philosophica et Theologica, 8(2), 148-164.

http://ejournal.stftws.ac.id/index.php/spet/article/view/166

Tim Detikcom. (2021). 6 Poin SKB 3 Menteri soal Seragam di Sekolah Negeri untuk SiswaSiswi. Https://News.Detik.Com/. https://news.detik.com/berita/d-5360544/6-poin-skb-3menteri-soal-seragam-di-sekolah-negeri-untuk-siswa-siswi

Unifikasi, J. (2015). Pemahaman Otonomi Daerah Dalam Perspektif. 2(2), 84-112.

Yulida Medistiara. (2021). SKB 3 Menteri untuk Sekolah Negeri, Tito: Seragam Harus Cerminkan Toleransi. Https://News.Detik.Com/. https://news.detik.com/berita/d5359947/skb-3-menteri-untuk-sekolah-negeri-tito-seragam-harus-cerminkantoleransi?_ga=2.108930690.124097271.1621089402-635142967.1611418912 